\title{
Üniversite Öğrencilerinin Toplumsal Cinsiyet Rolleri Algısı: Kadınlar Kendilerini Nasıl Güçlendirebilir?
}

\author{
DOI: 10.26466/opus.663605
}

*

\author{
Ali Belli*-Gülden Aynac1** \\ *Y. L. Öğrencisi,Toplumsal Cinsiyet ve Kadın Çalışmaları, Trakya Üniversitesi, Edirne / Türkiye \\ E-Posta: ali 0595@hotmail.com \\ ORCID: $\underline{0000-0001-7606-6290}$ \\ **Dr. Öğr. Üyesi, Sağllk Yüksekokulu, Trakya Üniversitesi, Edirne / Türkiye \\ E-Posta: guldenaynaci@hotmail.com \\ ORCID: $\underline{0000-0002-2112-8631}$
}

\section{Öz}

Toplumda karşılaşılan sosyal statü eşitsizliklerinden kadınlar en çok olumsuz etkilenen kesim olmaktadır. Kadınların toplumda bulunduğu statü ile direk olarak ilgisi olan bu durum, her alanda kadınların insan haklarından yararlanma konusunda, erkeklerle eşit olabilmesine engel olmaktadır. Bu eşitsizliklerin önüne geçilmesi önemlidir. Toplumun geleceğinin önemli bir yapıtaşı olan üniversite öğrencilerinin, toplumsal cinsiyet rollerine yönelik tutumlarının hangi yönde olduğunun öğrenilmesi faydal olacaktır. Böylece üniversitelerde verilen eğitimin içeriğine, toplumsal cinsiyet tutumlarına yönelik olarak eşitlikçi bir bakış açısının yerleşmesinde önemli bir katkıda bulunulacaktır. Çalışmamız Eylül 2019- Ocak 2020 tarihleri arasında Trakya Üniversitesi lisans öğrencileri ile yapıld. Araştırmanın evrenini Türkiye' deki üniversite öğrencileri, örneklemini Trakya Üniversitesi lisans eğitimi alan 466 üniversite öğrencisi oluşturdu. Araştırma kapsamında öğrencilerin sosyodemografik bilgilerini ve yaşam tarzların değerlendirmek üzere "Kişisel Bilgi Formu" kullanıldı. Kişisel bilgi formunda katılımcılara, toplumsal cinsiyet kavramın bilip bilmedikleri soruldu. Feminizme, miras paylaşımına ve kadın-erkek eşitliğine bakış açıları ile ilgili sorular yöneltildi. Öğrencilere "Toplumsal Cinsiyet Rolleri Tutum Ölçeği (TCRTÖ)" uygulandı. Toplumsal cinsiyete yönelik geleneksel görüşlere sahip olan lisans öğrencilerinin olması, üniversitelerin eğitim süreçlerinde, çă̆̆ yakalama hedefini tam anlamıyla gerçekleştiremediğini göstermesi bakımından düşündürücüdür. Bununla birlikte, hem sorunların hem çözümlerin kökeninde toplumsal dinamiklerin bulunduğu hatırlanmahdır. Toplumsal değgişimin bir süreç olduğu, çă̆daş medeniyet seviyesinde ilerlemeyi sürdürmek için, gençlerden başlamak gerekliliği de alınacak önlem ve önerilerin ilk aşamasıdır.

Anahtar Kelimeler: toplumsal cinsiyet, üniversite öğrencileri, toplumsal cinsiyet rolleri tutum ölçeği, kadın să̆lı̆̆ 


\title{
The Perception Of The Gender Roles Amongst University Students; How Can Women Empower Themselves?
}

\begin{abstract}
Women are the most adversely affected section by social status inequalities in the society. This situation, which is directly related to the status of women in society, prevents women from being equal to men in terms of benefiting from human rights in every field. It is important to avoid these inequalities. It will be useful to learn the direction of the university students' attitudes towards gender roles, which is an important building block of the future of the society. Thus, an important contribution will be made in the establishment of an egalitarian perspective on gender attitudes to the content of education provided in universities. Our study was conducted between September 2019 and January 2020 on undergraduate students of Trakya University. The research was carried out with 466 university students studying at Trakya University. "Personal Information Form" was used to evaluate the sociodemographic information of the students. Participants were asked if they knew the concept of gender. Questions were raised about their perspectives on feminism, heritage sharing and gender equality. The Gender Roles Attitude Scale (GRAS) was applied to the students. The fact that undergraduate students have traditional views on gender indicates that universities are not fully achieving the goal of catching the era in their educational processes. However, it should be remembered that social dynamics are at the root of both problems and solutions. The necessity of starting from young people is the first stage of the measures and suggestions to be taken, in order to maintain progress in the level of contemporary civilization, as the social change is a process.
\end{abstract}

Keywords: gender, university students, gender roles attitude scale, women's health 


\section{Giriş}

Türkiye'de eğitimde cinsiyet eşitliliği üzerine çalışmalar yıllardır devam etmektedir. Kaydedilen ilerlemeler, devam eden zorluklar üzerine düşünmek önemlidir. Toplumsal cinsiyet kavramına üniversite öğrencilerinin yaklaşımını anlayabilmek, genç nesilde toplumsal değişimleri yansıtması açısından önemlidir.

Toplumsal cinsiyet teriminin temelinde yatan başlica sorunlardan biri, kadın ve erkek olarak insanların toplum içindeki farklılıklarıdır. Bu farklılık; doğaları gereği mi ortaya çıkmaktadır, yoksa yaşadıkları toplumsal süreç mi onları farklı kllar? (West ve Fenstermaker, 2016) Bu sorun toplumsal cinsiyet kavramının tanımlanmasında ve tartışmasındaki ana merkezi temsil eder.

Cinsiyet kavramı, erkek ve kadın olarak insanların, biyolojik özelliklerindeki farklılıklarına göre sınıflandırılması olarak açıklanabilir. Toplumsal cinsiyet kavramı ise, toplum içerisindeki kadın ve erkeğin kültürel ve sosyal alandaki farklı tutum, rol ve davranışlarını açıklamak için kullanılan bir kavramdır (Goldscheider, Bernhardt, ve Lappegård, 2015). Açıkçası cinsiyet kavramı insanların fizyolojik ve anatomik farklılıklarıyla ilgilenirken, toplumsal cinsiyet kavramı ise kültürel ve toplumsal olarak kadın ve erkek arasındaki farklılıklarla ilgilenir.

Toplumsal yaşamda, çalışma yaşamında, aile ve evlilik yaşamında kadınlara yönelik olan ayrımcılıklar, kadınların sosyal yaşamlarındaki statülerini olumsuz olarak etkilemektedir. Bu sebeple geçmişten günümüze kadınlar çoğunlukla erkeklerin arkasında kalmış, istedikleri statülere ulaşamamış, erkekler ve kadınlar arasında eşitsizlikler meydana gelmiştir. Fakat günümüze yaklaştıkça, kadınların eğitim seviyelerinin yükselmesi, üniversite hayatına daha fazla girmeye başlamasıyla cinsiyetlerin üstlendiği gelenekçi roller kadınlar için olumlu şekilde değişiklik göstermeye başlamıştır (Boyd, Hunt, Kandell, ve Lucas, 2003; West ve Fenstermaker, 2016). Bu konunun ortaya çıarılması ve Türkiye'de bu konuda üniversitelerdeki öğrencilerin görüşlerinin belirlenmesi için daha çok çalışma yapılmasına ihtiyaç vardır. Gençlerin ihtiyaçlarına cevap verebilmenin başlıca yolu, öncelikle fikirlerini ve algilarını değerlendirmekten geçer.

Toplumda karşılaşılan sosyal statü eşitsizliklerinden kadınlar en çok olumsuz etkilenen kesim olmaktadır. Toplumdaki kadınların bulunduğu statü ile direkt olarak ilgisi olan bu durum, her alanda kadınların insan hak- 
larından yararlanma konusunda, erkeklerle eşit olabilmesine engel olmaktadır. Bu eşitsizliklerin önüne geçilmesi önemlidir (Zeyneloğlu ve Terzioğlu, 2011). Toplumun geleceğinin önemli bir yapıtaşı olan üniversite öğrencilerinin, toplumsal cinsiyet rollerine yönelik tutumlarının hangi yönde olduğunun öğrenilmesi faydalı olacaktır. Böylece üniversitelerde verilen eğitimin içeriğine, toplumsal cinsiyet tutumlarına yönelik olarak eşitlikçi bir bakış açısının yerleşmesine önemli bir katkıda bulunulacaktır.

\section{Amaç}

Bu çalışmadaTrakya Üniversitesi öğrencilerinin, toplumsal cinsiyete bakış açlarının değerlendirilmesi amaçlanmaktadır. Geleceğimizi emanet ettiğimiz eğitimli gençlerimizin bakış açısı ve etkileyen parametreler değerlendirilmektedir. Trakya Üniversitesinde eğitimine devam etmekte olan öğrencilerin toplumsal cinsiyet rolleri tutum ölçeği ile toplumsal cinsiyet rollerine yönelik algılarını ölçmek üzere yapılan bu çalışmada; öğrencilerin sosyodemografik özellikleri ve okudukları bölümlerle ilgili bilgiler ışığında toplumsal cinsiyet rolleri yönünden yaşamlarında toplumsal cinsiyete ait tutumlarının oluşup oluşmadığının incelenmesi ve araştırılması hedeflenmektedir.

\section{Yöntem}

Çalışmamız Eylül 2019- Ocak 2020 tarihleri arasında Trakya Üniversitesi lisans öğrencileri ile yapıldı. Araştırmanın evrenini Türkiye'deki üniversite öğrencileri, örneklemini Trakya Üniversitesi lisans eğitimi alan 466 üniversite öğrencisi oluşturdu. Araştırma kapsamında öğrencilerin sosyodemografik bilgilerini ve yaşam tarzların değerlendirmek üzere "Kişisel Bilgi Formu" kullanıldı. Kişisel bilgi formunda katılımcılara sosyodemografik özelliklerin yanında; bölümleri, toplumsal cinsiyet kavramını bilip bilmedikleri soruldu. Feminizme, miras paylaşımına ve kadın-erkek eşitliğine bakış açıları ile ilgili sorular yöneltildi.

Öğrencilere "Toplumsal Cinsiyet Rolleri Tutum Ölçeği (TCRTÖ)" uygulandı (Zeyneloğlu ve Terzioğlu, 2011). Ölçekten alınan veriler ve kişisel bilgi formu birlikte değerlendirildi, değişen parametreler ve ölçek arasında ilişki 
olup olmadığı incelendi. Gençlerde toplumsal cinsiyet rollerine ilişkin tutumlar ve etkileyen parametrelerin varlığı değerlendirildi.

Toplumsal Cinsiyet Rolleri Tutum Ölçeği (TCRT): GRAS; üniversite öğrenimine devam eden gençlerin, toplumsal cinsiyete dair yaklaşım ve görüşlerinin değerlendirilmesi için kullanılmaktadır. Beşli likert tipi olan bu ölçeğin geçerlik ve güvenirliği kanıtlanmıştır. 5 alt ölçekten oluşmaktadır (Zeyneloğlu \& Terzioğlu, 2011). Her bir alt ölçeğe ait sorulardaki yargılara, katılma düzeyine göre işaretleme yapmaları istenir. 5 puan; verilen cümledeki yargıya "tamamen katıldığını" ifade ederken; "katılıyorum" ifadesi için ise 4'ü işaretlemesi istenir. Kararsız olan öğrenci sorudan 3 puan alır. "Katılmıyor" ise; 2 puan; "kesinlikle katılmadığında" ise 1 puan almaktadır.

Katılımcıların TCRTÖ puanları artıkça, toplumsal cinsiyete daha 1 lımlı baktığı sonucuna varılmaktadır. Çalışmamızda, TCRTÖ 5 alt ölçeği de değerlendirildi. TCRTÖ'nün ilk alt ölçeği "eşitlikçi cinsiyet rolü”dür. Bu alt ölçekten alınan puanlar arttıkça, katılımcıların toplumsal cinsiyete eşitlikçi bakışı olduğu sonucuna varılmaktadır.

- İkinci alt ölçeği: "geleneksel cinsiyet rolü"dür. Bu alt ölçekten alınan puanlar arttıkça; eşitlikten uzaklaşma olduğu yargısına varıldı.

- Üçüncü alt ölçek olan "evlilikte cinsiyet rolü"nden alınan puanlar arttıkça, kadının evlilikte geri planda durması gerektiği düşüncesi ön plana çıkar.

- Dördüncü alt ölçek olan "kadın cinsiyet rolü"nden alınan puanlar arttıkça, kadın olmanın toplumsal cinsiyet açısından önemli olduğu sonucuna varılmaktadır.

- Beşinci alt ölçek; "erkek cinsiyet rolü"nden alınan puanlar arttıkça, erkek olmanin toplumsal cinsiyette daha etkin olduğunu savunan düşüncenin ağırlıkta olduğu sonucuna varıldı.

Etik Kurul Onayı: Trakya Üniversitesi Bilimsel Araştırmalar Etik kurulundan, çalışma için etik kurul onayı alındı (Karar No: 2019/ 431). Tüm katılımcılardan bilgilendirilmiş onam formlarını imzalamaları istendi. 


\section{İstatistiksel Analiz}

Toplanan verileri değerlendiren tüm istatistiksel analizler SPSS 20.0 Paket Programı kullanılarak gerçekleştirildi. Veriler uygun tanımlayıc istatistikler ile özetlendi. Sayısal değişkenler için ortalama, standart sapma; kategorik değişkenler için ise sıklık ve yüzde değerlendirildi. Verilerin normal dağılım kontrolü Shapiro-Wilk testi ile kontrol edildi. İkili grup karşılaştırmaları Student $\mathrm{t}$ testi ile yapıldı. Tek yönlü varyans analizi, ikiden fazla gruplar için karşılaştırmalarda kullanıldı. Tek yönlü varyans analizi sonrası çoklu karşılaştırmalar Bonferroni testi ile değerlendirildi. Kategorik değişkenler arasındaki ilişkiler için Ki-kare testi kullanıldı. Sayısal değişkenler için tanımlayıcı istatistikler, ortalama ve standart sapma olarak verildi. Kategorik değişkenler için tanımlayıcı istatistikler yüzde ve sıklık olarak verildi. Tüm istatistiksel analizlerde anlamlılık düzeyi \%5 olarak belirlendi.

\section{Bulgular}

Çalışmamız Eylül 2019-Ocak 2020 tarihleri arasında 479 gönüllü lisans öğrencileri ile yapıldı. 13 öğrenci çalışmamızdaki soruların tamamına yanıt vermediği için çalışma dışına çıkartıldı. 18-26 yaş, 466 gönüllü üniversite öğrencisi ile tamamlanan çalışmada; katılımcıların 342'si kız; 124'ü erkekti. Çalışmamızdaki katılımcıların yaş ortalaması 20,66 $\pm 1,79$ idi (Tablo 1).

Tablo 1. Katılımcılarn sosyodemografik özellikleri

\begin{tabular}{llll}
\hline Parametreler & $\mathbf{n}$ & Ortalama & Standart sapma \\
\hline Yaş & 466 & 20.66 & 1.79 \\
\hline TCRA & 466 & 61.37 & 13.47 \\
\hline Alt Ölçekler & 466 & & \\
\hline 1. Eşitlikçi cinsiyet rolü & 466 & 27.96 & 5.29 \\
\hline 2. Geleneksel cinsiyet rolü & 466 & 8.48 & 6.54 \\
\hline 3. Evlilikte cinsiyet rolü & 466 & 6.11 & 4.50 \\
\hline 4. Kadın cinsiyet rolü & 466 & 15.00 & 3.87 \\
\hline 5. Erkek cinsiyet rolü & 466 & 3.85 & 4.41 \\
\hline & & &
\end{tabular}

^^TCRA: Toplumsal Cinsiyet Rolleri Algısı Ölçeği, $n=466$

Katılımcların TCRTÖ'den aldıkları puanlara bakıldığında; puan ortalaması $61.37 \pm 13.47$ (35.00-122.00) idi. 5 alt ölçek için alınan puanlar incelendi. 
"Eşitlikçi cinsiyet rolünden" aldıkları puanın ortalaması $27.96 \pm 5.29$; "Geleneksel cinsiyet rolünden" aldıkları puanın ortalaması $8.48 \pm 6.54$ idi. "Evlilikte cinsiyet rolü alt ölçeği" puanı ortalaması $6.11 \pm 4.50$ idi. Kadın cinsiyet rolü alt ölçeği puanı ortalaması $15.00 \pm 3.87$ idi. Erkek cinsiyet rolü alt ölçeği puanı ortalaması $3.85 \pm 4.41$ idi (Tablo 1 ).

Tablo 2. Katılımcılarn Toplumsal Cinsiyet Rolleri Algısının, Sosyodemografik özelliklere göre değişimi

\begin{tabular}{|c|c|c|c|c|c|c|c|c|c|c|}
\hline \multirow[t]{2}{*}{ Parametreler } & \multicolumn{3}{|c|}{ TCRA } & \multicolumn{4}{|c|}{ 1. alt ölçek eşitlikçi } & \multicolumn{3}{|c|}{ 2.alt ölçek geleneksel } \\
\hline & $\mathbf{n}$ & Ort & $\begin{array}{l}\text { Standart } \\
\text { sapma }\end{array}$ & $\mathrm{p}$ & Ort & $\begin{array}{l}\text { Standart } \\
\text { sapma }\end{array}$ & $\mathrm{p}$ & Ort & $\begin{array}{l}\text { Standart } \\
\text { sapma }\end{array}$ & $\mathrm{p}$ \\
\hline \multicolumn{11}{|l|}{ Cinsiyet } \\
\hline Kadın & 342 & 68.55 & 16.01 & $<0.001^{*}$ & 29.31 & 4.13 & $<0.001^{*}$ & 6.67 & 5.45 & $<0.001^{*}$ \\
\hline Erkek & 124 & 58.77 & 11.37 & & 24.22 & 6.26 & & 13.49 & 6.71 & \\
\hline \multicolumn{11}{|l|}{ Kardeş sayısı } \\
\hline 2 & 125 & 63.60 & 16.85 & & 27.93 & 5.19 & & 7.72 & 6.60 & \\
\hline 3 & 160 & 63.71 & 14.57 & & 27.21 & 5.64 & & 9.61 & 6.92 & \\
\hline \multicolumn{11}{|c|}{ Yaşamınızı nerede sürdürdünüz? } \\
\hline $\begin{array}{l}\text { Köy, } \\
\text { kasaba }\end{array}$ & 81 & 60.60 & 13.96 & $0.011^{*}$ & 26.69 & 5.87 & $0.026^{*}$ & 11.13 & 6.70 & $<0.001^{*}$ \\
\hline \multicolumn{11}{|c|}{ Memleketiniz hangi coğrafi bölgemizdir? } \\
\hline Marmara & 268 & 67.07 & 17.58 & $0.022^{*}$ & 28.36 & 4.83 & $<0.001^{*}$ & 8.22 & 6.17 & $<0.001^{*}$ \\
\hline Ege & 91 & 58.94 & 12.12 & & 28.86 & 5.02 & & 6.81 & 5.68 & \\
\hline $\begin{array}{l}\text { İç } \\
\text { Anadolu }\end{array}$ & \multicolumn{9}{|c|}{ Anadolu } & \\
\hline $\begin{array}{l}\text { Güneydoğu- } \\
\text { Doğu } \\
\text { Anadolu }\end{array}$ & 63 & 60.84 & 12.08 & & 25.46 & 6.17 & & 11.71 & 7.07 & \\
\hline Karadeniz & 25 & 60.80 & 13.69 & & 28.04 & 5.17 & & 7.96 & 7.40 & \\
\hline \multicolumn{11}{|c|}{ Bölümünüz hangisidir? } \\
\hline Eşit ağırlık & 36 & 63.75 & 19.20 & 0.999 & 27.41 & 6.75 & 0.238 & 10.13 & 8.35 & 0.565 \\
\hline Sayısal & 305 & 61.16 & 12.75 & & 28.11 & 5.35 & & 8.19 & 6.15 & \\
\hline Sözel & 125 & 61.21 & 13.26 & & 27.76 & 4.65 & & 8.72 & 6.86 & \\
\hline \multicolumn{11}{|c|}{ Toplumsal cinsiyet kavramını daha önce duydunuz mu? } \\
\hline Evet & 411 & 66.40 & 11.44 & $<0.001^{*}$ & 28.35 & 5.04 & $<0.001^{*}$ & 8.00 & 6.45 & $<0.001^{*}$ \\
\hline Hayır & 55 & 60.70 & 13.59 & & 25.07 & 6.20 & & 12.10 & 6.13 & \\
\hline \multicolumn{11}{|c|}{ Feminizm konusunda bilginiz var mu? } \\
\hline Evet & 428 & 70.44 & 13.96 & $<0.001^{*}$ & 28.28 & 5.05 & $<0.001^{*}$ & 8.03 & 6.40 & $<0.001^{*}$ \\
\hline Hayır & 38 & 60.57 & 13.14 & & 24.39 & 6.57 & & 13.57 & 5.98 & \\
\hline \multicolumn{11}{|c|}{ Sizce Türk toplumunda eşitlikte söz etmek mümkün mü? } \\
\hline Evet & 183 & 60.33 & 12.63 & 0.101 & 27.37 & 5.44 & 0.053 & 9.65 & 6.95 & $0.004^{*}$ \\
\hline Hayır & 283 & 62.98 & 14.56 & & 28.34 & 5.16 & & 7.73 & 6.16 & \\
\hline \multicolumn{11}{|c|}{ Sizce mirasta kime daha çok pay verilmelidir? } \\
\hline Kadın & 20 & 68.45 & 13.86 & $<0.001^{*}$ & 25.75 & 7.15 & $<0.001^{*}$ & 12.45 & 5.23 & $<0.001^{*}$ \\
\hline Eşit & 417 & 75.00 & 16.71 & & 28.51 & 4.76 & & 7.67 & 5.99 & \\
\hline Erkek & 29 & 60.09 & 12.57 & & 21.58 & 6.54 & & 17.41 & 7.50 & \\
\hline
\end{tabular}


Gençlerin toplumsal cinsiyet rolleri algıları, sosyodemografik özelliklerine göre incelendi. Erkek öğrencilerin TCRTÖ ortalaması $58.77 \pm 11.37$ idi. $\mathrm{K}$ zz öğrencilerin ortalaması $68.55 \pm 16.01$ idi. Her iki cinsiyet arasında ölçek toplam puanlarında anlamlı faklılık vard1 $(\mathrm{p}<0.001)$. Bunun yanında TCRTÖ alt ölçekleri için de, kız ve erkekler arasında istatistiksel anlamlı farklılık vardı ( $\mathrm{p}$ 0.001). Kızlarda eşitlikçi alt ölçek puanları yüksek iken; erkeklerde geleneksel alt ölçek puanları yüksek idi (Tablo 2).

Tablo 3. Katılımcılarn TCRA alt ölçeklerinin, katılımcılarn özelliklerine göre değişimi

\begin{tabular}{|c|c|c|c|c|c|c|c|c|c|c|}
\hline \multirow[t]{2}{*}{ Parametreler } & \multicolumn{4}{|c|}{ 3. alt ölçek evlilikte } & \multicolumn{2}{|c|}{ 4. alt ölçek kadın } & \multicolumn{4}{|c|}{ 5.alt ölçek erkek } \\
\hline & $\mathbf{n}$ & Ort & $\begin{array}{l}\text { Standart } \\
\text { sapma }\end{array}$ & $\mathrm{p}$ & Ort & $\begin{array}{l}\text { Standart } \\
\text { sapma }\end{array}$ & $\mathbf{P}$ & Ort & $\begin{array}{l}\text { Standart } \\
\text { sapma }\end{array}$ & $\mathbf{P}$ \\
\hline \multicolumn{11}{|l|}{ Cinsiyet } \\
\hline Kadın & 342 & 5.11 & 3.26 & $<0.001^{*}$ & 15.97 & 4.37 & $<0.001^{*}$ & 3.02 & 3.53 & $<0.001^{*}$ \\
\hline Erkek & 124 & 8.86 & 6.08 & & 14.65 & 3.62 & & 6.12 & 5.63 & \\
\hline \multicolumn{11}{|l|}{ Kardeş Sayısı } \\
\hline 0 & 25 & 7.12 & 6.22 & \multirow[t]{4}{*}{$0.001^{*}$} & 14.68 & 4.12 & \multirow[t]{4}{*}{0.499} & 4.28 & 5.40 & \multirow[t]{4}{*}{0.187} \\
\hline 1 & 156 & 5.29 & 3.69 & & 14.73 & 3.89 & & 3.41 & 3.83 & \\
\hline 2 & 125 & 5.72 & 4.40 & & 15.09 & 3.42 & & 3.40 & 4.18 & \\
\hline 3 & 160 & 7.06 & 4.82 & & 15.25 & 4.15 & & 4.56 & 4.87 & \\
\hline \multicolumn{11}{|c|}{ Yaşamınızı nerede sürdürdünüz? } \\
\hline Köy, kasaba & 81 & 6.67 & 4.84 & \multirow[t]{3}{*}{0.278} & 15.39 & 3.75 & \multirow[t]{3}{*}{0.292} & 4.80 & 4.77 & \multirow[t]{3}{*}{0.065} \\
\hline İlçe & 177 & 6.07 & 4.21 & & 15.07 & 3.72 & & 3.80 & 4.39 & \\
\hline İl merkezi & 208 & 5.93 & 4.62 & & 14.80 & 4.05 & & 3.52 & 4.24 & \\
\hline \multicolumn{11}{|c|}{ Memleketiniz hangi coğrafi bölgemizdir? } \\
\hline Marmara & 268 & 5.61 & 3.90 & \multirow[t]{6}{*}{$<0.001^{*}$} & 15.00 & 3.75 & \multirow[t]{6}{*}{0.934} & 3.67 & 3.95 & \multirow[t]{6}{*}{0.057} \\
\hline Ege & 91 & 5.31 & 3.81 & & 14.89 & 3.39 & & 3.13 & 4.15 & \\
\hline İç Anadolu & 19 & 7.94 & 7.09 & & 14.26 & 3.24 & & 3.84 & 5.31 & \\
\hline $\begin{array}{l}\text { Güneydoğu- } \\
\text { Doğu }\end{array}$ & 63 & 8.73 & 5.66 & & 15.46 & 4.98 & & 5.66 & 5.71 & \\
\hline Anadolu & & & & & & & & & & \\
\hline Karadeniz & 25 & 6.40 & 4.84 & & 14.92 & 14.92 & & 3.76 & 4.70 & \\
\hline \multicolumn{11}{|c|}{ Bölününüz hangisidir? } \\
\hline Eşit ağırlık & 36 & 7.36 & 6.45 & \multirow[t]{3}{*}{0.569} & 14.61 & 5.25 & \multirow[t]{3}{*}{0.176} & 4.22 & 5.67 & \multirow[t]{3}{*}{0.597} \\
\hline Sayısal & 305 & 5.98 & 4.38 & & 15.17 & 3.74 & & 3.77 & 4.41 & \\
\hline Sözel & 25 & 6.08 & 4.09 & & 14.71 & 3.72 & & 3.92 & 4.01 & \\
\hline \multicolumn{11}{|c|}{ Toplumsal cinsiyet kavramını daha önce duydunuz mu? } \\
\hline Evet & 411 & 5.91 & 4.45 & \multirow[t]{2}{*}{$<0.001^{*}$} & 14.80 & 3.90 & \multirow[t]{2}{*}{$<0.001^{*}$} & 3.67 & 4.46 & \multirow[t]{2}{*}{$<0.001^{*}$} \\
\hline Hayır & 55 & 7.58 & 4.65 & & 16.52 & 3.25 & & 5.20 & 3.80 & \\
\hline Feminizm kor & usunda & bilginiz & var $\mathrm{mı}$ ? & & & & & & & \\
\hline Evet & 428 & 5.80 & 4.24 & $<0.001^{*}$ & 14.89 & 3.88 & $0.010^{*}$ & 3.60 & 4.32 & $<0.001^{*}$ \\
\hline Hayır & 38 & 9.60 & 5.81 & & 16.34 & 3.50 & & 6.65 & 4.50 & \\
\hline Sizce Türk top & lumund & a eşitlik & ten söz etn & mümkün & & & & & & \\
\hline Evet & 183 & 6.67 & 4.93 & $0.016^{*}$ & 15.13 & 3.95 & 0.808 & 4.23 & 4.52 & 0.080 \\
\hline Hayır & 283 & 5.75 & 4.18 & & 14.92 & 3.83 & & 3.60 & 4.33 & \\
\hline Sizce mirasta & ime dal & a çok p & ay verilme & & & & & & & \\
\hline Kadın & 20 & 7.25 & 4.86 & $<0.001^{*}$ & 16.65 & 4.61 & $0.002^{*}$ & 6.45 & 5.52 & $<0.001^{*}$ \\
\hline Eşit & 417 & 5.68 & 3.87 & & 14.79 & 3.80 & & 3.43 & 4.00 & \\
\hline Erkek & 29 & 11.48 & 8.08 & & 16.89 & 3.65 & & 8.10 & 6.19 & \\
\hline
\end{tabular}


Erkek öğrencilerin düşünceleri değerlendirildiğinde, evlilikte erkek cinsiyet rolünün baskın geldiği izlendi $(\mathrm{p}<0.001)$. Kadınlar için ise, kadın cinsiyet rolünün erkeklere göre daha yüksek olduğu görülmektedir $(\mathrm{p}<0.001)$ (Tablo 3).

Kardeş sayısına göre incelendiğinde; toplam ölçek puanları açısından farklılık saptanmadı. Eşitlikçi alt ölçek puanları az kardeşi olanların en düşük olduğu görülmektedir. Kardeş sayıSı arttıkça TCRTÖ puanında artma izlendi ( $\mathrm{p}=0.058$ ). Kardeş sayısı ile geleneksel alt ölçeği arasındaki değişime bakıldığında; üçten fazla kardeşi olanların puanları daha yüksek idi ( $\mathrm{p}=$ 0.027) (Tablo 2). Kadın ve erkek alt ölçekleri ile kardeş sayısı arasında ilişki bulunamadı. Evlilikte erkek cinsiyet rolünün baskın olduğunu düşünenler; ya kardeşi hiç olmayanlar ya da 3 ten fazla kardeşi olanlar olduğu görülmektedir. 1 veya 2 kardeşe sahip olanların evlilikte erkeğin baskın olduğunu düşünmemekteydiler (Tablo 3).

Öğrencilere yaşamlarını nerde sürdürdükleri soruldu. Köy ve kasabalardan gelenlerin, toplam ölçek puanları; il ve ilçe merkezindekilerden daha düşük idi ( $p=0.011)$. Eşitlikçi alt ölçek puanları ise ilçelerden gelen gençlerin daha yüksekti $(p=0.026)$. Geleneksel alt ölçek puanları ise, köy ve kasabalardan gelenlerin daha yüksek olduğu görülmektedir (Tablo 2). Yaşadıkları yerlere göre gruplandırıldıklarında öğrencilerin 3., 4., 5. alt ölçek puanları ortalamaları arasında istatistiksel anlamlı farklılık bulunamadı (Tablo 3).

Öğrenciler memleketlerine göre 5 gruba ayrıldı. 268 öğrenci Marmara Bölgesi'nden gelmekteydi. 91 öğrencinin Ege, 19 öğrencinin İç Anadolu, 63 öğrencinin Güneydoğu ve Doğu Anadolu, 25 öğrencinin Karadeniz Bölgesi memleketi idi. TCRTÖ puanı en yüksek olan öğrenciler Marmara Bölgesi'nden gelenler idi ( $p=0.022)$. Eşitlikçi alt ölçek puanları en yüksek olanlar, Ege Bölgesi'nden gelen öğrenciler idi. Geleneksel alt ölçek puanları en yüksek olan öğrenciler ise, İç Anadolu ve Güneydoğu Anadolu' dan gelenler olduğu görülmektedir $(\mathrm{p}<0.001)$ (Tablo 2).

Katılımcıların memleketleri ile, kadın ve erkek alt ölçek puanları açısından fark yoktu. Evlilikte eşitlik ölçek puanları, Türkiye'nin doğusuna gittikçe artmakta idi $(\mathrm{p}<0.001)$ (Tablo 3).

Öğrencilerin 305'i sağlık lisans öğrencisi iken; 125 öğrenci uygulamalı teknik bilimler öğrencisi, 36 öğrenci eğitim bilimleri öğrencisi idi. TCRTÖ puanları ve 5 alt ölçek puanları arasında istatistiksel anlamlı farklılık saptanmadi (Tablo 2). 
Çalışmamızdaki öğrencilerin 55'i (\% 11.80) toplumsal cinsiyet kavramını hiç duymadığını belirtti. Toplumsal cinsiyet kavramını duymuş olanlar ile duymuş olmayanlar arasında, TCRTÖ puanları açısından farklılık vardı $(\mathrm{p}<$ 0.001). Eşitlikçi alt ölçekten yüksek puan alanların toplumsal cinsiyet kavramını daha önce duyduğunu belirten öğrenciler olduğu görülmektedir. İkinci alt ölçek olan geleneksel toplumsal cinsiyet alt ölçeğinden yüksek puan alanların, bu kavramı duymamış olanlar olduğu görülmektedir (Tablo 2). Toplumsal cinsiyet kavramı hakkında fikri olmayanların, alt ölçeklerdeki puanlarının da, eşitlikçi düşünceden uzaklaşmakta olduğu görülmektedir. Erkek egemenliğinin toplumda baskın olması gerektiği yaklaşımı bu cevabı veren öğrencilerde izlendi $(\mathrm{p}<0.001)$ (Tablo 3).

Feminizm konusunda hiç bilgisi olmayanlar 38 kişi (\%8.15) idi. Feminizm konusunu daha önce duymuş olanların TCRTÖ puanları daha yüksekti $(\mathrm{p}<0.001)$ (Tablo 2). Feminizm konusunu duydukların ifade edenlerin, eşitlikçi alt ölçek puanları daha yüksek idi, geleneksel görüşün baskın olduğu alt ölçek puanları ise düşüktü $(\mathrm{p}<0.001)$ (Tablo 2).

Kadın-erkek eşitliğinin toplumumuzda olduğunu düşünen gençlerin sayısı 183 (\%39.27) idi. 283 kişi (\% 60.73) ise, toplumumuzda eşitlik olmadığı yönünde görüş bildirdi. TCRTÖ puanları, eşitlik olduğunu düşünenlerde daha düşük idi. Yine toplumuzda eşitlik olduğunu düşünen katılımclara bakıldığında, eşitlik olmadığını düşünenlere göre; kadın cinsiyet rolü ve evlilikte cinsiyet rolü alt ölçek puanları daha yüksek idi (Tablo 3). Türk toplumunda eşitlik olduğunu belirtenlerin geleneksel cinsiyet rolü alt ölçeği puanları da yüksek idi ( $\mathrm{p}=0.004)$ (Tablo 2). Eşitlikçi cinsiyet rolü, kadın cinsiyet rolü, erkek cinsiyet rolü alt ölçekleri açısından farklılık saptanmadı (Tablo 3).

Miras konusundaki görüşleri sorulduğunda ise; 20 (\%4.29) kişi kadınlara 29 (\%6.22) kişi erkeklere daha çok pay verilmesi gerektiğini belirtti. 417 katılımcl, eşit verilmesi gerektiğini düşünmekteydi. Eşit verilmesi gerektiğini düşünenlerin, TCRTÖ puanları, eşitlikçi cinsiyet rolü alt ölçek puanları daha yüksek iken; erkek cinsiyet rolü ve kadın cinsiyet rolü alt ölçekleri puanları arasında farklılık vardı (Tablo 3).

Çalışmamızda ölçeğe ait bazı sorular detaylı incelendi. Her alt ölçekten birer soruya verilen cevapları etkileyen sosyodemografik özellikler incelendi. Eşitlikçi cinsiyet rolü olan ilk alt ölçekten seçilen soru: "ev işlerinin ailede eşit paylaşımına yaklaşımınız nedir" sorusu idi. Kız öğrenciler ile erkekler 
arasında görüş ayrılı̆̆ belirgindi. Kızlar \%92.70 eşit paylaşımdan yanaydı ( $\mathrm{p}<0.001$ ). Toplumsal cinsiyet kavramin daha önce duyanlar ve feminizmin anlamını bildiklerini ifade edenler, ev işlerinde eşitlikten yana idi (Tablo 4).

Tablo 4. Katılımcılarn bazı TCRA sorularna verdikleri yantlarn, bazı parametrelere göre değişimi

\begin{tabular}{|c|c|c|c|c|c|c|c|c|c|c|}
\hline \multirow[t]{2}{*}{ Parametreler } & \multirow[t]{2}{*}{$n$} & \multicolumn{3}{|c|}{$\begin{array}{l}\text { Ev işlerinin eşit } \\
\text { paylaşımı olmalıdır. }\end{array}$} & \multicolumn{3}{|c|}{$\begin{array}{l}\text { Genç kızların flört etmesine } \\
\text { izin verilmelidir. }\end{array}$} & \multicolumn{3}{|c|}{$\begin{array}{l}\text { Evde erkeğin her dediği } \\
\text { yapılmalıdır. }\end{array}$} \\
\hline & & $\begin{array}{l}\text { Katıl } \\
\text { miyorum }\end{array}$ & $\begin{array}{l}\text { Katılı } \\
\text { yorum }\end{array}$ & $\mathrm{p}$ & $\begin{array}{l}\text { Katılm1- } \\
\text { yorum }\end{array}$ & $\begin{array}{l}\text { Katıliyo- } \\
\text { rum }\end{array}$ & $\mathrm{p}$ & $\begin{array}{l}\text { Katılmi- } \\
\text { yorum }\end{array}$ & $\begin{array}{l}\text { Katıliyo- } \\
\text { rum }\end{array}$ & $\mathbf{P}$ \\
\hline \multicolumn{11}{|l|}{ Cinsiyet } \\
\hline Kadın & 342 & $\% 7.30$ & $\% 9270$ & \multirow[t]{2}{*}{$<0.001^{*}$} & $\% 32.10$ & $\% 67.90$ & \multirow[t]{2}{*}{-} & $\% 98.90$ & $\% 1.10$ & \multirow[t]{2}{*}{$<0.001^{*}$} \\
\hline Erkek & 124 & $\% 40.40$ & $\% 59.60$ & & $\% 62.10$ & $\% 37.90$ & & $\% 82.20$ & $\% 17.80$ & \\
\hline \multicolumn{11}{|l|}{ Kardeş sayısı } \\
\hline 0 & 25 & $\% 12.00$ & $\% 88.00$ & \multirow[t]{4}{*}{0.722} & $\% 32.00$ & $\% 68.00$ & \multirow[t]{4}{*}{0.064} & $\% 96.00$ & $\% 4.00$ & \multirow[t]{4}{*}{0.114} \\
\hline 1 & 156 & $\% 14.70$ & $\% 85.30$ & & $\% 34.00$ & $\% 66.00$ & & $\% 94.90$ & $\% 5.10$ & \\
\hline 2 & 125 & $\% 17.60$ & $\% 82.40$ & & $\% 39.20$ & $\% 60.80$ & & $\% 93.60$ & $\% 6.40$ & \\
\hline 3 & 160 & $\% 16.90$ & $\% 83.10$ & & $\% 48.20$ & $\% 51.80$ & & $\% 94.40$ & $\% 5.60$ & \\
\hline \multicolumn{11}{|c|}{ Yaşamınızı nerede sürdürdünüz? } \\
\hline $\begin{array}{l}\text { Köy, } \\
\text { kasaba }\end{array}$ & 81 & $\% 23.50$ & $\% 76.50$ & \multirow[t]{3}{*}{0.339} & $\% 42.00$ & $\% 58.00$ & \multirow[t]{3}{*}{0.473} & $\% 92.60$ & $\% 7.4$ & \multirow[t]{3}{*}{0.693} \\
\hline ìlçe & 177 & $\% 14.80$ & $\% 85.20$ & & $\% 35.10$ & $\% 64.90$ & & $\% 94.40$ & $\% 5.60$ & \\
\hline İl merkezi & 208 & $\% 14.40$ & $\% 85.60$ & & $\% 43.70$ & $\% 56.30$ & & $\% 95.10$ & $\% 4.90$ & \\
\hline \multicolumn{11}{|c|}{ Memleketiniz hangi coğrafi bölgemizdir? } \\
\hline Marmara & 268 & $\% 15.30$ & $\% 84.70$ & \multirow[t]{5}{*}{0.083} & $\% 38.10$ & $\% 61.90$ & \multirow[t]{5}{*}{$0.009^{*}$} & $\% 94.80$ & $\% 5.2$ & \multirow[t]{5}{*}{$0.003^{*}$} \\
\hline Ege & 91 & $\% 9.90$ & $\% 90.10$ & & $\% 33.00$ & $\% 77.00$ & & $\% 94.50$ & $\% 5.5$ & \\
\hline $\begin{array}{l}\text { İç } \\
\text { Anadolu }\end{array}$ & 19 & $\% 21.10$ & $\% 78.90$ & & $\% 42.10$ & $\% 57.90$ & & $\% 84.20$ & $\% 15.80$ & \\
\hline $\begin{array}{l}\text { Güneydoğu- } \\
\text { Doğu Anado- } \\
\text { lu }\end{array}$ & 63 & $\% 25.30$ & $\% 74.70$ & & $\% 58.80$ & $\% 41.20$ & & $\% 96.90$ & $\% 3.1$ & \\
\hline Karadeniz & 25 & $\% 20.00$ & $\% 80.00$ & & $\% 40.00$ & $\% 60.00$ & & $\% 88.00$ & $\% 12.00$ & \\
\hline \multicolumn{11}{|c|}{ Bölümünüz hangisidir? } \\
\hline Eşit ağırlık & 36 & $\% 16.70$ & $\% 83.30$ & \multirow[t]{3}{*}{0.365} & $\% 30.50$ & $\% 69.50$ & \multirow[t]{3}{*}{0.350} & $\% 94.50$ & $\% 5.50$ & 0.987 \\
\hline Sayısal & 305 & $\% 15.00$ & $\% 85.00$ & & $\% 38.60$ & $\% 61.40$ & & $\% 94.40$ & $\% 5.60$ & \\
\hline Sözel & 25 & $\% 18.40$ & $\% 81.60$ & & $\% 46.40$ & $\% 53.60$ & & $\% 94.40$ & $\% 5.60$ & \\
\hline Toplumsal cin & siyet $k$ & raminı da & önce du & unuz mu & & & & & & \\
\hline Evet & 411 & $\% 13.30$ & $\% 86.70$ & $<0.001^{*}$ & $\% 37.50$ & $\% 62.50$ & 0.036 & $\% 94.90$ & $\% 5.10$ & 0.560 \\
\hline Hayır & 55 & $\% 35.40$ & $\% 64.60$ & & $\% 60.00$ & $\% 40.00$ & & $\% 90.90$ & $\% 9.10$ & \\
\hline Feminizm hak & kinda & lginiz var & & & & & & & & \\
\hline Evet & 428 & $\% 14.60$ & $\% 85.40$ & $0.010^{*}$ & $\% 38.10$ & $\% 61.90$ & $<0.001^{*}$ & $\% 95.80$ & $\% 4.20$ & $<0.001^{*}$ \\
\hline Hayır & 38 & $\% 31.60$ & $\% 68.40$ & & $\% 63.20$ & $\% 36.80$ & & $\% 78.90$ & $\% 21.10$ & \\
\hline Sizce Türk top & lumur & a eşitlikteı & söz etmek & ümkün & & & & & & \\
\hline Evet & 183 & $\% 19.60$ & $\% 80.40$ & 0.056 & $\% 41.00$ & $\% 59.00$ & 0.674 & $\% 92.80$ & $\% 7.20$ & $0.036^{*}$ \\
\hline Hayır & 283 & $\% 13.70$ & $\% 86.30$ & & $\% 39.50$ & $\% 60.50$ & & $\% 95.40$ & $\% 4.60$ & \\
\hline Sizce mirasta 1 & kime d & a çok pay & erilmelidi & & & & & & & \\
\hline Kadın & & $\% 20.00$ & $\% 80.00$ & $<$ & $\% 45.00$ & $\% 55.00$ & $<0.001^{*}$ & $\% 90.00$ & $\% 10.00$ & $<0.001^{*}$ \\
\hline Eşit & & $\% 13.20$ & $\% 86.80$ & $0.001^{*}$ & $\% 37.90$ & $\% 62.10$ & & $\% 96.70$ & $\% 3.30$ & \\
\hline Erkek & & $\% 55.10$ & $\% 44.90$ & & $\% 68.90$ & $\% 31.10$ & & $\% 65.50$ & $\% 34.50$ & \\
\hline
\end{tabular}


İkinci alt ölçek olan "geleneksel cinsiyet rolü" ölçeğinden seçilen soru; "kadının yapacağı meslekler ile, erkeğin yapacağı meslekler ayrıdır" önerisine katılım oranları incelendi. Erkek öğrencilerin \% 50.80'i bunun doğru olduğunu düşünmekte idi (Tablo 5).

Tablo 5. Katılımcılarn bazı TCRA sorularna verdikleri yanıtlarn, bazı parametrelere göre değişimi

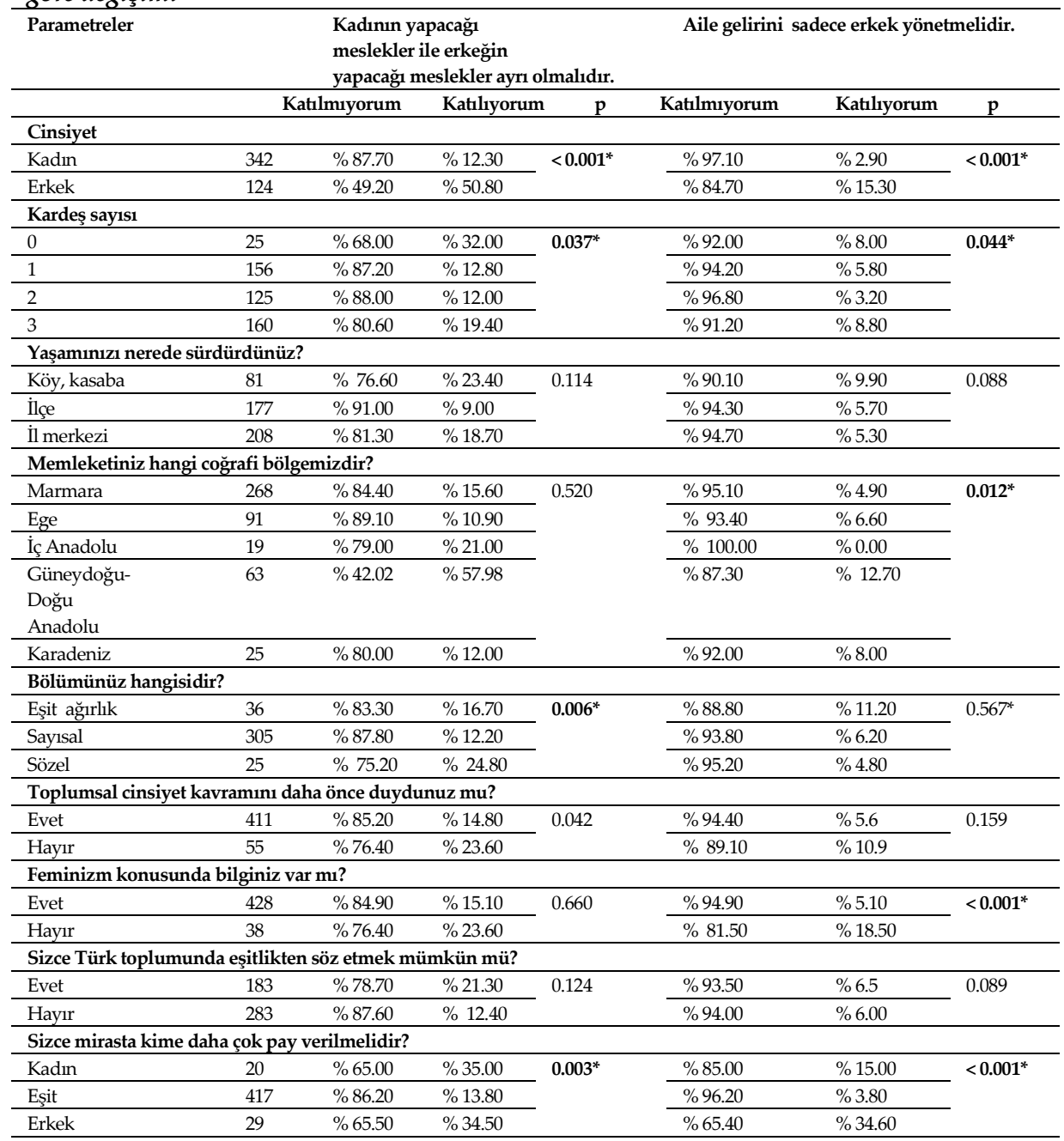


Üçüncü alt ölçek olan "evlilikte cinsiyet rolü" alt ölçeğinden, "evde erkeğin her dediği yapılmalıdır" yargısına verdikleri yanıtlar incelendi. Genç kızların \% 98.90'u bu yargiya katılmazken; erkeklerin de \% 82.20'si katılmıyordu. Feminizm hakkında bilgisi olmadığını ifade edenlerin, feminizm konusunda bilgisi olduğunu söyleyenlere göre, evde erkeklerin her dediğinin yapılması gerektiğini düşünme oranları daha fazlayd 1 ( $\mathrm{p}<0.001)$ (Tablo 4).

Dördüncü alt ölçek olan, kadın cinsiyet rolü alt ölçeğinde incelenen yarg1; "genç kızların flört etmesine ailesi izin vermelidir" idi. Kız öğrenciler \% 67.90 katılırken, erkekler \% 62.10 katılmıyordu. Feminizm hakkında bilgisi olduğunu ifade edenlerin \% 61.90’u genç kızların erkek arkadaşı olmasına ailesinin izin vermesi gerektiğini düşünüyordu (Tablo 4).

Beşinci alt ölçek olan "erkek cinsiyet rolü" alt ölçeğinden; "ailede gelirin yönetimi erkekte olmalıdır" sorusu detaylandırıldı. Erkek öğrencilerin \%15.30'u doğru olduğunu belirtirken; kadınların ise \% 2.90'u bu yargiya katılmaktaydı. Feminizm konusunda fikri olmayanların \%18.50'si bu yargiya katılmaktaydı.Mirastan erkeğe daha fazla pay verilmesi gerektiğini savunanların \%34.60'ı aile gelirini erkeğin yönetmesi gerektiğini düşünüyordu (Tablo $5)$.

\section{Sonuç ve Tartışma}

Toplumsal cinsiyet, bütün dünyada ortak bir kadınlık erkeklik kimliğinin var olup olmadığı tartışmalarının ardından ortaya çıkmıştır. Toplumsal cinsiyet, toplumsal hayatta kadın ve erkeğe yüklenen rol ve sorumlulukları barındırır. İnsanların, sosyal yerlerinin belli olduğunu, sadece bu yerleri kadın rollerini kadınların, erkek rollerini ise erkeklerin doldurmasın bekler. Üniversiteler de; toplumda hakim olan kültür anlayışını yeniden üreten bir yapı olarak, toplumsal cinsiyet davranışlarını destekleyen unsurları barındırır. Okuldaki; cinsiyet söylemleri, uygulanan müfredatlar, işbölümü cinsiyet kavramlarının yeniden üretilmesinde etkindir (Baker, 2016; Lips, 2017). Her dönemde üniversiteler toplumsal cinsiyet rollerinin öğrenilmesinde önemli bir yer tutar.

Gençlerin toplumsal cinsiyet algısı pek çok farklı etkenler tarafından ortaya çıkmakta ve bu yapı bireylerin hayatının her alanında farklı biçimlerde de olsa etkisini göstermektedir (Ihlen \& Fredriksson, 2018; West \& Fenstermaker, 2016). Toplumsal cinsiyet, sosyal ortamlarda en küçük birim olan 
aile kurumundan başlayarak, aile içindeki rol modelleri gözlem yoluyla öğrenilmektedir. Bütün sosyalleşme süreçlerinde kadın ve erkek olarak gençler bu normları içselleştirir ve öğrenirler. Gençlerin bakış açısına değer verilmesi, toplumun geleceğine yapılacak en önemli yatırımlardandır.

Toplumsal cinsiyet rolleri, sosyal yapının içinde ve sosyal ortamlarda kadınlığın ve erkekliğini ifade ediliş biçimi ve kültürün bireylerden beklediklerini ortaya koyar (Boyd et al., 2003; Goldscheider et al., 2015). Çalışmamızda da, erkeklere uygun olduğunu düşünülen davranışlar erkeksi, kadınlara uygun olduğu düşünülen davranışlar ise kadınsı olarak nitelendirilmiştir. Bu tanımla kadınsı-erkeksi davranışların cinsiyet kavramından bağımsız bir şekilde ifade edilmesinin yanında kişilerin içinde oldukları ortama göre geleneksel özellik gösterdiği gözlenmiştir. Aile yapısı daha kompakt olan gençlerin geleneksel görüşleri ağırlık kazanmıştır.

Literatürde, toplumsal cinsiyet sadece kadınlar üzerinden analiz edilmiş olması sebebiyle anlamsal olarak zamanla dar gelmeye başlamıştır. Erkekler büyük oranda bu kavram alanının dişarısında kalmıştır. Cinsel bir devrim ile toplumsal cinsiyet kavramının prangalarından kadınlarla birlikte erkeklerin de kurtulacağı düşünülmektedir. Ataerkil yapı kadınları hapsettiği gibi erkeklerin de hapsolduğu anlayışı, son zamanlarda dile getirilmeye başlanmış ve toplumsal cinsiyet kavramının tanımı ve kapsamı genişletilerek kadın ve erkek her iki cinsiyetin de bu yapıdan etkilendiği ve her iki cinsiyetin de bu kavram sebebiyle ortaya çıan eşitsizliklerin ortaya kaldırılması için birlikte mücadele etmesi gerektiği ortaya atılmıştır (Beck ve BeckGernsheim, 2018). Kadınlar nasıl eve ve ev işlerine hapsolduysa, erkekler de eve para getirmeleri ve evi geçindirmeleri konusunda iş rollerine hapsolmuşlardır. Çalışmamızda da, erkek öğrencilerin yarısının, profesyonel iş hayatında, kadınların erkeklerle eşit olamayacağını belirtmişlerdir.

Kadın ve erkekler arasındaki davranış farklılıklarının ortaya çıkışıyla ilgili birden fazla yaklaşım vardır. En sık karşımıza çıan, bu farklılıkların biyolojik kaynaklı olduğudur. Bir diğer yaklaşıma göre, toplumsallaşan cinsiyet rollerinin toplumun içinde doğduktan sonra öğrenildiğidir. En yaygın görüsslerden bir diğeri ise, cinsiyet ve toplumsal cinsiyet kavramlarının biyolojik temellerinin olmadığı ve bu kavramların toplum tarafından ortaya çıkarıldığına yönelik görüştür (Boyd et al., 2003; Goldscheider et al., 2015; West ve Fenstermaker, 2016). Çalışma yaşamı ve kadın ile yapılan çalışmalarda; erkek öğrencilerin, kadının çalışma yaşamına katılımına ilişkin görüş- 
lerinin cinsiyet ayrımcllı̆ı̆ını destekler nitelikte olduğu dikkati çekmektedir (Fogarty, Allen, Allen, ve Walters, 2016). Bizim çalışmamızda erkek üniversite öğrencileri erkeklerin daha farklı ve kaliteli meslekler de çalışmaları gerektiğini savunmaktayd.

Yapılan araştırmalarda; gençlerin cinsiyetlerine göre aile yaşamı ile ilgili önermelere ilişkin bakış açıları incelendiğinde, mirastan sadece erkek çocuklarının yararlanma hakkı olduğun savunan görüşler olduğu görüldü (Pateman, 2018). Çalışmamızda, eşit verilmesi gerektiği görüşü ağırlık kazansa da; erkek öğrencilerden \% 23.38'i, mirasın sadece erkeklere verilmesi gerektiğini düşünüyordu.

Üniversiteli gençlerin çalışma yaşamı, toplumsal yaşam ve aile yaşamı ile ilgili toplumsal cinsiyet rollerine ilişkin görüşleri incelendiğinde, erkek öğrencilerin kız öğrencilere göre daha geleneksel bir bakış açısına sahip oldukları göze çarpmaktadır. Ancak evlilik yaşamı ile ilgili önermeleri değerlendirdiğimizde; kız öğrencilerin erkek öğrencilere göre daha geleneksel bir bakış açısına sahip oldukları görülmektedir (Powell, 2018). Çalışmamızda, erkek öğrencilerin geleneksel alt ölçekten aldıkları puanlar daha yüksekti. Kız öğrencilerin eşitlikçi alt ölçekten aldıkları puanlar daha yüksekti. Toplumumuzda gençlerimizin aydınlık bir geleceğe ulaşabilmeleri için; değer yargılarının bilinmesi gerektiği unutulmamalıdır. Özellikle genç erkek üniversite öğrencilerinin eğitim seviyesinin yükseltilmesi ile, toplumsal cinsiyete eşitlikçi bakış açısı genişleyecektir.

Gençlerin cinsiyetlerine göre evlilik yaşamı ve aile yaşamı şekillenmektedir (Zeyneloğlu ve Terzioğlu, 2011). Ailede evin reisinin erkek olması gerektiği, ailede ev işlerinin sorumluluğunun yalnızca kadında olması gerektiği, erkek öğrenciler tarafından daha ağırlıklı olarak benimsenmektedir (Oakley, 2018; Powell, 2018). Çalışmamız da evlilikte cinsiyet rolü ve evde erkeğin her istediğinin yapılması yargılarını incelediğimizde; erkek katılımcıların eşitlik görüşünden uzaklaştıkları görüldü. Genç lisans öğrencilerinden oluşan katılımcılarımızın, toplumun aydın kesimi arasına girmektedir. Ancak görülmektedir ki; özellikle erkek öğrencilerin toplumsal cinsiyet eşitliği için alması gereken daha çok yol vardır.

Genç nesillerde, toplumsal yaşam incelendiğinde; kız ve erkeklerin görüşleri arasında anlamlı farklılıklar vardır. Erkek üniversite öğrencileri, kadının çalışma yaşamında ön planda olmasını desteklememektedir. Erkek öğrencilerin, kız öğrencilere göre çalışma yaşamında daha geleneksel bakış 
açısına sahip oldukları görülmektedir (Baker,2016; Powell, 2018). Literatürle uyumlu olarak çalışmamızda da, erkek ve kadının yapacağı mesleklerin farklı olduğunu, aile gelirinin erkeğin idaresinde olduğunu düşünenler daha çok erkek öğrenciler idi. Erkeklerin toplumsal cinsiyet eşitliğine daha az inanmalarının nedeni; toplum tarafından da destek görmeleri ve yararlarına olan bu durumdan faydalanmakta olmalarıdır.

Yapılan çalışmalarda, üniversite öğrencilerinin, toplumsal cinsiyet rollerine ilişkin görüşleri incelendiğinde; mesleki ve evlilik yaşamlarında; erkek öğrenciler kız öğrencilere göre daha geleneksel görüşlere sahiplerdir (Glick ve Fiske, 2018; Powell, 2018). Çalışmamızda, toplumsal yaşam ve aile yaşamı ile ilgili konularda; kız ve erkek öğrencilerin bazı alanlarda eşitlikçi, kız öğrencilerin evlilik alanında geleneksel, erkek öğrencilerin mesleki yaşamda geleneksel davranabildiği göze çarpmaktadır.

Üniversite öğrencilerinin ailelerinin yaşadığı yerler de, düşüncelerinin şekillenmesinde önemlidir. Öğrencilerin ailelerinin yaşadığı yerlere göre toplumsal cinsiyete bakışları değişmektedir. Ailelerin köy, ilçe ya da ilde yaşamalarına göre farklılaşmaktadır. Yaşamlarını daha çok il ve ilçe merkezinde geçirmiş olanların toplumsal cinsiyette eşitlik algıları; kasaba ve köylerde yaşayanlardan daha yüksektir (Powell, 2018; Spain, 1992). Çalışmamız da literatürle uyumlu şekilde; yaşadığı yerin gelişmişliği arttıkça; öğrencilerin geleneksel yaklaşımdan uzaklaşarak; eşitlikçi yaklaşıma sahip olduğu görüldü.

Literatürde, kardeş sayısı ile toplumsal cinsiyet rollerine dair tutumlar değişmektedir. Kardeş sayısı arttıkça, eşitlikçi yaklaşımın yükseldiği belirtilmektedir (Dhar, Jain, ve Jayachandran, 2019; Powell, 2018). Çalışmamızda, kardeş sayısı ile; TCRTÖ puanları aynı yönde artmaktaydı. Kardeş sayısı arttıkça, eşitlikçi düşünceye sahiptiler.

Genç neslin, ailede kararların erkek ve kadın tarafından birlikte verilmesi gerektiğini düşündüğü yapılan çalışmalar da gösterilmiştir (Boyd et al., 2003; Galanti, 2003). Bizim çalışmamızda da, kız öğrenciler erkeklerin her dediğinin yapılmaması gerektiğini savunurken, erkek öğrencilerde de erkeğin evde tek karar verici olması gerektiğini düşünenlerin oranı \% 17.80'di. Bir başka deyiş ile aslında erkeklerin de çoğunluğu, aile kararlarında her zaman tek başlarına sorumluluk almak istemediklerini belirtti.

Toplumsal cinsiyet kavramı, toplumsal ilişkileri anlamak ve yorumlamak için önemli bir yönelim sağlamaktadır. Bu yönle birlikte toplumun 
içinde var olduğu kabul edilen ideoloji, güç ilişkileri ve toplumda yer alan sınıf gibi kavramların yorumlanıp daha iyi anlaşılmasını mümkün kılar (Ihlen \& Fredriksson, 2018). Yine bu açıdan bakarak ailede, toplumsal yapılarda ve üniversitelerde yer alan egemen düşüncelerin nasıl yer aldığı hakkında ipuçları incelenmelidir.

Eşlerin evde görev ve sorumlulukların paylaşımında adil olması kültürlerarası farklılıklar göstermektedir. Kadın ve erkekler arasında bir görüş ayrılığı da bu konuda ortaya çıkmaktadır. Evlilikte cinsiyet rolü ve erkek cinsiyet rolüne yaklaşım; erkek öğrencilerde, kızlara göre daha geleneksel çerçevede kalmaktadır (Boyd et al., 2003; Galanti, 2003). Çalışmamızda; eşitlikçi cinsiyet rolünü yansıtan; ev işlerinin eşit paylaşımı olmalıdır, yargıSı incelendi. Öğrencilerin, ev işlerinin eşit paylaşımı yaklaşımlarına bakıldığında; kızların \% 92.70'i onaylarken, erkeklerin \% 59.60'ı onaylamaktaydı. Erkeklerin de bu yaklaşımı dikkat çekiciydi. Ev işlerinin eşit paylaşılması gerekliliği fikrinin; kardeş sayısı ve il merkezinde yaşama oranı artıkça daha fazla savunulmakta olduğu görülmektedir. Aile ve sosyal çevrenin çocuğun yaşamının şekillenmesindeki değeri eşsizdir. Eğitimin aile bireylerinin hepsini kapsayacak şekilde verilmesi, toplumun cinsiyet rolleri algisı üzerine eşitlikçi yaklaşımın desteklenmesi, toplumsal refahı arttıracaktır.

Çalışmamız Türkiye'de üniversite öğrencilerinde, toplumsal cinsiyet alanında yapılan nadir çalışmalar arasındadır. Öğrencilerin toplumsal cinsiyet rollerine ait genel yaklaşımları eşitlikçi tutuma sahip olduklarını göstermektedir. Ancak detaylı değerlendirildiğinde erkek öğrencilerin, geleneksel cinsiyet rolü, evlilikte cinsiyet rolü ve erkek cinsiyet rolünde daha geleneksel davrandığı izlenmektedir.

\section{Öneriler}

Çalışmamız üniversite öğrencilerinin toplumsal cinsiyete ilişkin görüşlerini ortaya koyması açısından önem taşımaktadır. Çağdaş nesiller yetiştirmeyi hedeflemiş olan üniversite eğitim ve öğretiminde toplumsal cinsiyet bakış açısının yeri önemlidir. Toplumsal cinsiyete yönelik geleneksel görüşlere sahip olan lisans öğrencilerinin olması, üniversitelerin eğitim süreçlerinde, çağı yakalama hedefini tam anlamıla gerçekleştiremediğini göstermesi bakımından düşündürücüdür. Bunun yanında gelenekselleşmiş ataerkil düşünce kalıplarının kısa zamanda değiştirilerek yerine eşitlikçi yaklaşımla- 
rın yerleştirilebilmesi gerçekçi bir yaklaşım değildir. Bununla birlikte, sorunların ve çözümlerin kökeninde toplumsal dinamiklerin bulunduğu hatırlanmalıdır. Toplumsal değişimin bir süreç olduğu, çağdaş medeniyet seviyesinde ilerlemeyi sürdürmek için bir noktadan başlamak gerekliliği de alınacak önlem ve önerilerin ilk aşamasıdır.

Üniversitelerde kadınların, gerek öğrenci gerek öğretim görevlisi olarak üniversitelerin gelişimi ve ilerlemesine katkıları göz ardı edilmemelidir. Yapılacak değerlendirmelerle, kadınların kariyerlerinde müdahalelerin etkinliği kritik noktalarda test edilerek, planlanacak stratejilerle genç kızların ve toplumun geleceği için eşsiz katkılar sağlanabilir.

Gençlerin toplumsal cinsiyet bakış açılarını daha geniş çapta belirlemek için üniversitelerde araştırmalar desteklenmelidir. Ülkemizde bölgesel farklılıkları ortaya çıarmak amacı ile farklı üniversitelerde toplumsal cinsiyet araştırmalarının yapılması önerilir. Toplumsal cinsiyet eşitsizliğine ilişkin düzenlenen eğitimler ile üniversite öğrencilerinin farklı üniversitelerde bilgi ve görüşlerini paylaşmalan desteklenebilir. Toplumsal cinsiyet eşitliğine yönelik araştırma birimlerinin kurulması ve bu tür etkinliklere erkek öğrencilerin katılımının desteklenmesi önemlidir.

Teşekkür: İstatistiksel değerlendirmeler için Dr. Öğr. Üyesi Selçuk Korkmaz'a teşekkür ederiz. 


\title{
EXTENDED ABSTRACT
}

\section{The Perception Of The Gender Roles Amongst University Students; How Can Women Empower Themselves?}

\author{
Ali Belli - Gülden Aynacı \\ Trakya University
}

Studies on gender equality in education in Turkey continue for years. It is important to reflect on progress made, ongoing challenges. Understanding the approach of university students to the concept of gender is important in terms of reflecting social changes in the young generation.One of the main problems underlying the term gender is the differences of people in society as men and women. This problem represents the main center in the definition and discussion of the concept of gender. Women are the most affected by the social inequality in the society. It is important to prevent these inequalities. It will be useful to learn the direction of university students' attitudes towards gender roles, which is an important building block of the future of society. Thus, an important contribution will be made to the content of education provided at universities and to establish an egalitarian perspective towards gender attitudes. In this study, it was aimed to evaluate the perspectives of students of Trakya University on gender. The perspective of our educated young people whom we entrust our future and the influencing parameters were evaluated. In this study, which was conducted to measure the perceptions of students who continue their education at Trakya University towards gender roles attitude scale and gender roles; In the light of the socio-demographic characteristics and knowledge of the students, it was aimed to examine whether gender attitudes were formed in their lives in terms of gender roles. Our study was conducted between September 2019 and January 2020 with Trakya University undergraduate students. The universe of the research university students in Turkey, Trakya University undergraduate study sample constituted the area of 466 university students. Within the scope of the research, "Personal Information Form" was used to evaluate the sociodemographic information and lifestyles of the students. In 
the personal information form, besides the socio-demographic characteristics; they were asked if they knew the sections, the concept of gender. Questions regarding feminism, heritage sharing and perspectives on gender equality were asked."Gender Roles Attitude Scale (GRAS)" was applied to students. The data taken from the scale and the personal information form were evaluated together, and whether there was a relationship between the changing parameters and the scale was examined. Attitudes towards gender roles in young people and the presence of influencing parameters were evaluated. It is used to evaluate the gender approaches and views of young people who continue their university education. The validity and reliability of this scale, which is a five-point Likert type, has been proved. It consists of 5 subscales. They are asked to mark the judgments in the questions of each subscale according to their level of participation. Our study of university students in Turkey is among the few studies in the field of gender. The general approaches of students regarding gender roles show that they have an egalitarian attitude. However, when evaluated in detail, it is observed that male students behave more traditionally in traditional gender role, gender role in marriage and male gender role.Our study is important in terms of revealing the gender opinions of university students. The role of gender perspective is important in university education and training, which aims to raise contemporary generations. Having undergraduate students who have traditional views on gender is thought-provoking in terms of showing that universities cannot fully achieve the goal of catching up in their education. In addition, it is not a realistic approach to replace the traditional patriarchal thought patterns in a short time and replace them with egalitarian approaches. It should be remembered, however, that social dynamics are at the root of problems and solutions. It is the first stage of the measures and suggestions to be taken, from which a social change is a process, the necessity of starting from a point in order to continue to progress at the level of modern civilization.The contribution of women in universities to the development and advancement of universities as students and lecturers should not be ignored. With the evaluations to be made, the effectiveness of interventions in women's careers can be tested at critical points, and the strategies to be planned can make unique contributions to the future of young girls and society.Research at universities should be supported to more broadly determine the gender perspectives of young people. In order to reveal regional 
differences in our country, it is recommended to conduct gender studies in different universities. With the trainings on gender inequality, university students can be supported to share their knowledge and opinions at different universities. It is important to establish research units for gender equality and to support the participation of male students in such activities.

\section{Kaynakça / References}

Baker, D. R. (2016). Equity issues in science education Understanding girls. Springer. 127-160.

Beck, U., ve Beck-Gernsheim, E. (2018). The normal chaos of love. John Wiley \& Sons.

Boyd, V. S., Hunt, P. F., Kandell, J. J., ve Lucas, M. S. (2003). Relationship between identity processing style and academic success in undergraduate students. Journal of College Student Development, 44(2), 155-167.

Dhar, D., Jain, T., ve Jayachandran, S. (2019). Intergenerational transmission of gender attitudes: Evidence from India. The Journal of Development Studies, 55(12), 2572-2592.

Fogarty, M. P., Allen, A., Allen, I., ve Walters, P. (2016). Women in top jobs: Four studies in achievement. Routledge.

Galanti, G.-A. (2003). The Hispanic family and male-female relationships: An overview. Journal of Transcultural Nursing, 14(3), 180-185.

Glick, P.ve Fiske, S. T. (2018). The ambivalent sexism inventory: Differentiating hostile and benevolent sexism Social CognitionRoutledge.116-160

Goldscheider, F., Bernhardt, E., ve Lappegård, T. (2015). The gender revolution: A framework for understanding changing family and demographic behavior. Population and Development Review, 41(2), 207-239.

Ihlen, Ø., ve Fredriksson, M. (2018). Public relations and social theory: Key figures, concepts and developments. Routledge.

Lips, H. M. (2017). Sex and gender: An introduction. Waveland Press.

Oakley, A. (2018). The sociology of housework (reissue). Policy Press.

Pateman, C. (2018). The disorder of women: Democracy, feminism and political theory. John Wiley \& Sons.

Powell, G. N. (2018). Women and men in management. Sage Publications.

Spain, D. (1992). Gendered spaces. Univ of North Carolina Press.

West, C., ve Fenstermaker, S. (2016). Doing difference race, gender and class. Routledge.83-105. 
Zeyneloğlu, S., ve Terzioğlu, F. (2011). Development and psychometric properties gender roles attitude scale. Hacettepe Üniversitesi Ĕ̆itim Fakültesi Dergisi, 40(40), 409-420.

\section{Kaynakça Bilgisi / Citation Information}

Belli, A. ve Aynac1, G.(2020).Üniversite öğrencilerinin toplumsal cinsiyet rolleri algisi: Kadınlar kendilerini nasil güçlendirebilir?.OPUSUluslararası Toplum Araştırmaları Dergisi, 15(26), 4208-4229. DOI: 10.26466/opus.663605 